\title{
The participative budget of making a city sustainable: quintuple helix approach
}

\author{
Mykola Petrushenko ${ }^{1, *}$, and Carsten Grunwaldt ${ }^{2}$ \\ ${ }^{1}$ Institute of Market Problems and Economic-Ecological Research of the National Academy of Sciences of Ukraine, Department of \\ Economic Management of Natural Resources, 29 Frantsuz'kyy Blvd., Odesa, 65044, Ukraine \\ ${ }^{2}$ DAAD, 50 Kennedyallee, D-53175 Bonn, Germany
}

\begin{abstract}
For transition economies, urban management processes are also in transition, which also means a situational opportunity to apply an integrated approach to the implementation of innovative projects, in which economic and political, as well as social, socio-cultural and environmental directions of development can receive a positive stimulus. Purpose of the study is to analyze the structure of participatory budgeting projects on the continuum "science and education - environment", in accordance with the methodological approach to justify the innovative development of the city (based on helix-modeling). The paper has outlined an approach to activation the principles of sustainable and inclusive development at the local level, on the example of the participatory budget of Kyiv city in Ukraine. At the methodological level, the stages of the evolution of helix-modeling to the quintuple level have been analyzed in detail, the results of which are proposed to be implemented in accelerating the transformation of the projects structure aimed at the development of economic, social and environmental aspects of citizens life, namely in the fields of education, science, culture, sports, ecology, etc. Analysis of the change in the structure of participatory budgeting in Kyiv for the period 2017-2019 allows us to talk about the optimistic transition scenario of the city and the country in whole to the real pace of achievement the Sustainable Development Goals 2030. Strengthening the current positive changes with the help of state support, as well as ensuring a sufficient responsible investment, allows at a project level to succeed in improving the sustainability of the city.
\end{abstract}

\section{Introduction}

Urban sustainability is one of the current areas of research within the concept of sustainable development [1-3]. In the conditions of transformation [4], the specificity of the situation lays not so much in the smart city - the global trend of urban planning and urban ecology of the last decade, but in the constant maintenance of sustainable and innovative urban development.

Contrary to the fact, that scientific sphere in Ukraine as of 2020 is in the situation of waiting for reforms; innovation activity begins exactly in this sphere. And then from here innovations gradually spread to other spheres of society life and development of the country and its cities. From education and science begins allencompassing progress, in which business and industry, the public and activities related to the environment are involving. It is clear that without state support it is impossible to stabilize the sustainable development of cities and achieve the Global Goals at the international [5] and national [6] levels (especially Goal 11 "Sustainable cities and communities"), given the possible threats and impact of crisis factors.

Along with direct investment, an important tool for provision of sustainable urban development is a participatory budgeting. Since this process is relatively new for Ukraine, it is advisable to theoretically substantiate it on the basis of approaches to innovation modeling, which complement the approaches to modeling the relevant investment processes $[7 ; 8]$.

It is also advisable to make extensive use of foreign experience in participatory budgeting. At the beginning of the $21 \mathrm{st}$ century, Europe adopted this sustainable mechanism from Latin America and, as of 2010, applied it in dozens of cities. The participatory budgeting gained the greatest development in Italy, Portugal, Spain, France, Germany, and the United Kingdom. The most common models of the participatory budgeting development in Western Europe are as follows: participatory democracy (clearly defined rules, good quality deliberation; combining strong participation with social justice), proximity democracy (informal rules, deliberative quality weak or average; combining participation with formal decision-making process) and participatory modernization (rules may be clear, weak deliberative quality; broad political consensus) [9]. In Germany, for almost two decades, participatory budgeting has evolved from a symbolic political instrument to improve communication between citizens and administration [10] to a mechanism for democratic innovation and municipal modernization [11].

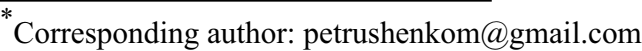




\section{Methodology}

The conceptual basis of the study is an evolutionary approach to innovation development modeling - the helix-modeling (Fig. 1), which includes six types of models (three prototype models and three helix models), as well as five gradual stages of transition from one model to another: from a linear model to a quintuple helix model, which summarizes the following elements of innovation development: science and education, business and industry, government and state support, the civil society, the environment and the social environment.

The proposed approach was used to analyze the dynamics of structural changes in the short term (20172019) on the example of the formation and use of participatory budget at the municipal level, namely the example of Kyiv city.

The information base is the online platform [18], on which project data is constantly updated.

The evolutionary approach in the context of changing the forms of descriptive helix-model, when it is transferred to the plane of formation of the participatory budget of the city, allows to identify features of its innovative development and to substantiate expediency of acceleration of transformation of projects structure.

\section{Results}

The logic of the study consists of, firstly, on the actualization of a set interrelated factors of sustainable development, including reflection in indicators that characterize the social and environmental components of sustainability and inclusiveness, at the level of the economic region of Ukraine, the center of which is Kyiv city; and also, secondly, on the implementation of the analysis of the structure of project directions within the participatory budget of Kyiv city on the basis of an evolutionary approach to helix-modeling of innovation activity.

\subsection{Rating analysis of sustainable and inclusive development indicators of the territory}

When conducting analysis of sustainable and inclusive development indicators of the Central economic region of Ukraine, their comparison with similar indicators of other economic regions of Ukraine were carried out and, accordingly, the results of the rating assessment were obtained (Table 1). The results (above all, the first place by level of higher education, as well as the second place by level of Internet access) prove the existence of preconditions, and therefore the expediency of innovative modeling of participatory budgeting in Kyiv. Also the composition of the main problems can be seen preliminarily (for example, VII place - overcrowding housing or VI place - the inability to satisfy recreational services), which, on the one hand, reflect the situation in the country, and, on the other hand, indicate bottlenecks in urban development and therefore it should affect the structure of the participatory budget of Kyiv.

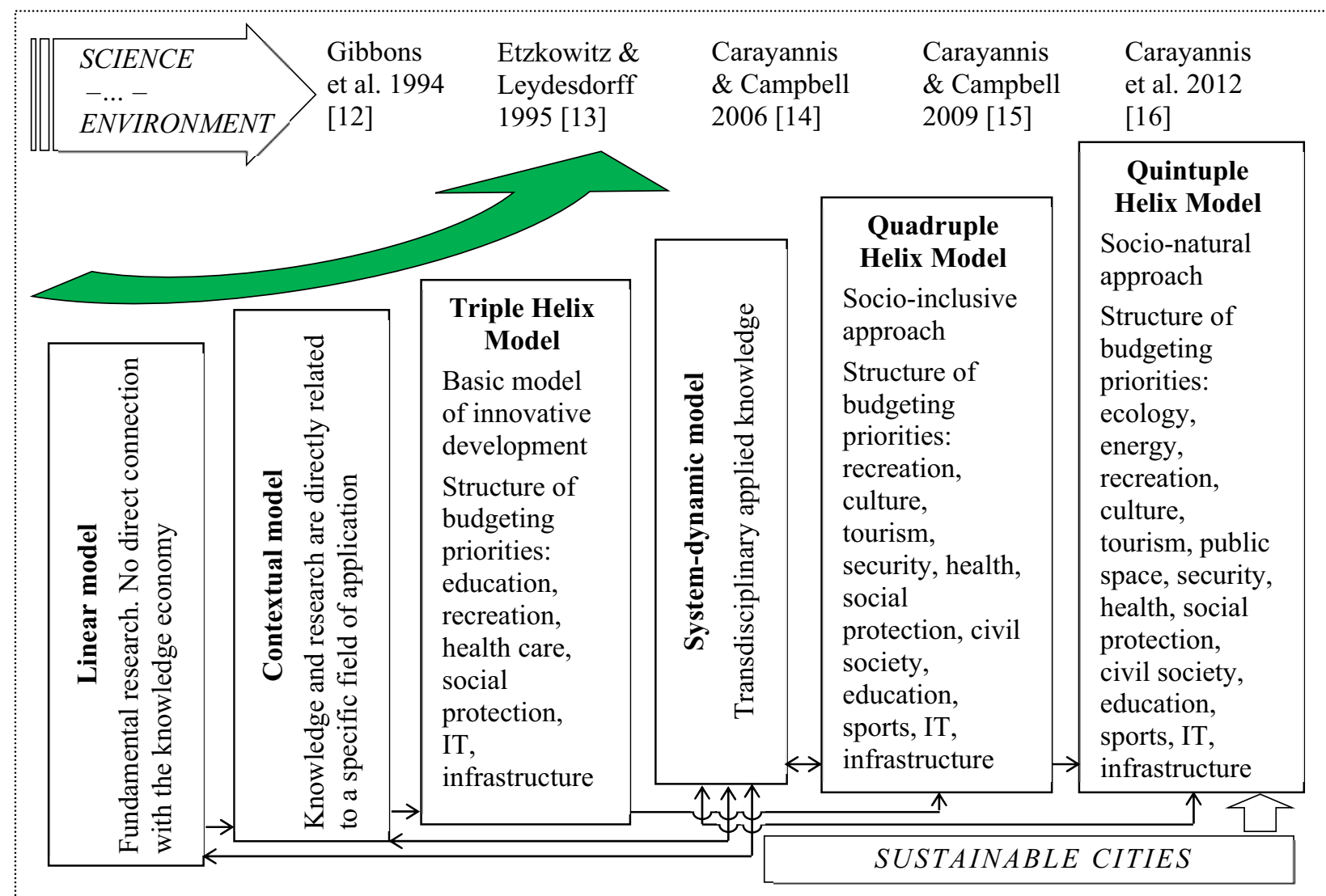

Fig. 1. The evolution of helix-models and its sustainable context (based on [16; 17]). 
Table 1. Comparative analysis of sustainable and inclusive development indicators of the Central economic region of Ukraine, 2019 (according to [19;20]).

\begin{tabular}{|l|c|c|}
\hline \multicolumn{1}{|c|}{ Indicators } & Value & Ranking \\
\hline $\begin{array}{l}\text { Number of household members who rated } \\
\text { their health as good, thousand }\end{array}$ & 3112,25 & II \\
\hline $\begin{array}{l}\text { Number of household members who rated } \\
\text { their health as bad, thousand }\end{array}$ & 424,49 & III \\
\hline $\begin{array}{l}\text { Households whose members constantly } \\
\text { denied themselves the most necessary, in } \\
\text { addition to food, thousand }\end{array}$ & 654,30 & III \\
\hline $\begin{array}{l}\text { Share of persons suffering from 4 or more } \\
\text { signs of material deprivation of 9 signs, \% }\end{array}$ & 14,90 & II \\
\hline $\begin{array}{l}\text { Share of population living in overcrowded } \\
\text { housing, \% }\end{array}$ & 54,50 & VII \\
\hline $\begin{array}{l}\text { Share of households that are (very) } \\
\text { dissatisfied with housing conditions, \% }\end{array}$ & 13,10 & II \\
\hline $\begin{array}{l}\text { Share of households that are (very) } \\
\text { satisfied with housing conditions, \% }\end{array}$ & 60,60 & I \\
\hline $\begin{array}{l}\text { Number of persons who can allow } \\
\text { minimum recreational services, thousand }\end{array}$ & 2298,80 & VI \\
\hline $\begin{array}{l}\text { Number of persons who reported that they } \\
\text { used Internet services at least once a day, } \\
\text { thousand }\end{array}$ & 2952,60 & II \\
\hline $\begin{array}{l}\text { Number of households with Internet access } \\
\text { at home, thousand }\end{array}$ & 1553,00 & II \\
\hline $\begin{array}{l}\text { Share of population with complete higher } \\
\text { education, \% }\end{array}$ & 33,80 & I \\
\hline $\begin{array}{l}\text { Number of persons living in households } \\
\text { who could not afford unexpected necessary } \\
\text { expenses, thousand }\end{array}$ & 2861,50 & VI \\
\hline The average indicator of ecological status & 10,00 & III \\
\hline & - & I \\
\hline
\end{tabular}

3.2 Evolution of helix-modeling and its projection into the plane of formation of innovative ecologically oriented, educational and other socially significant projects

That, how helix-modeling evolved is shown in Figures 26: from a linear model that reflects the activities of educational and research institutions (Fig. 2, upper left corner) to a model that includes five interconnected components, integrated in the joint innovation process quintuple helix model (Fig. 6).

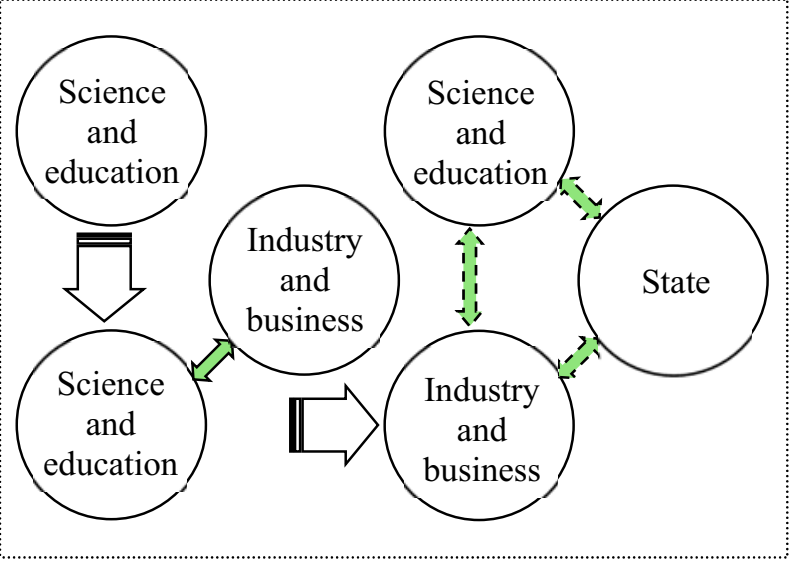

Fig. 2. Triple helix-modeling scheme for innovation activity in emerging countries (based on [21]).

The structure of participatory budgeting in Kyiv is presented in Table 2.

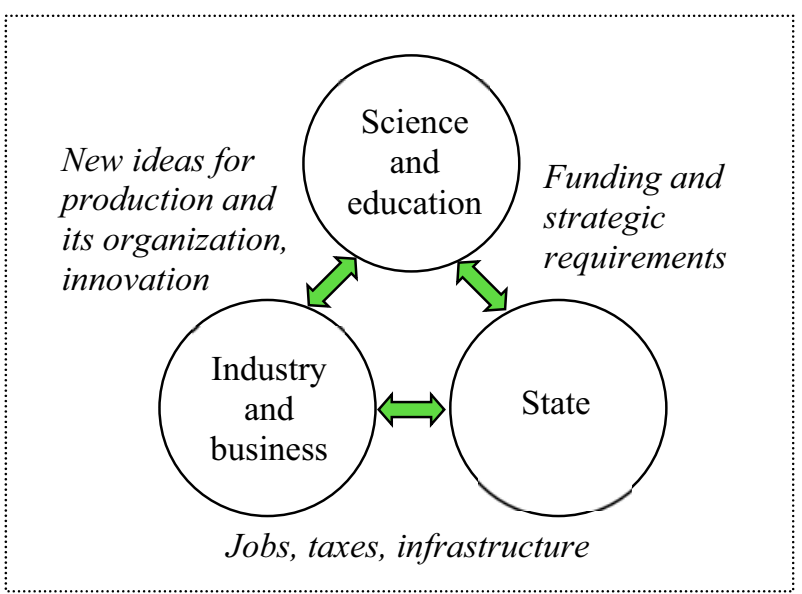

Fig. 3. Triple Helix-modeling scheme for innovation activity in countries with economies in transition (based on [21]).

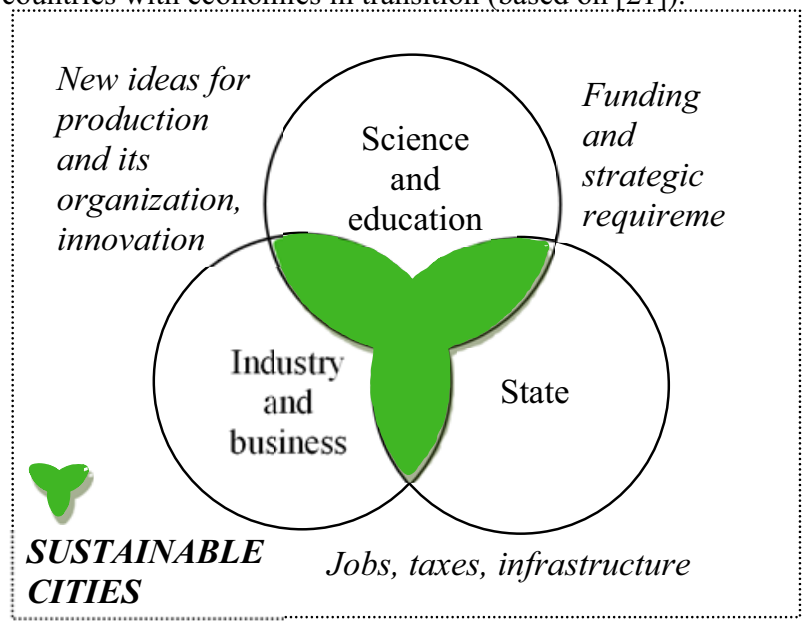

Fig. 4. Triple helix-modeling scheme for innovation activity in developed countries (based on [21]).

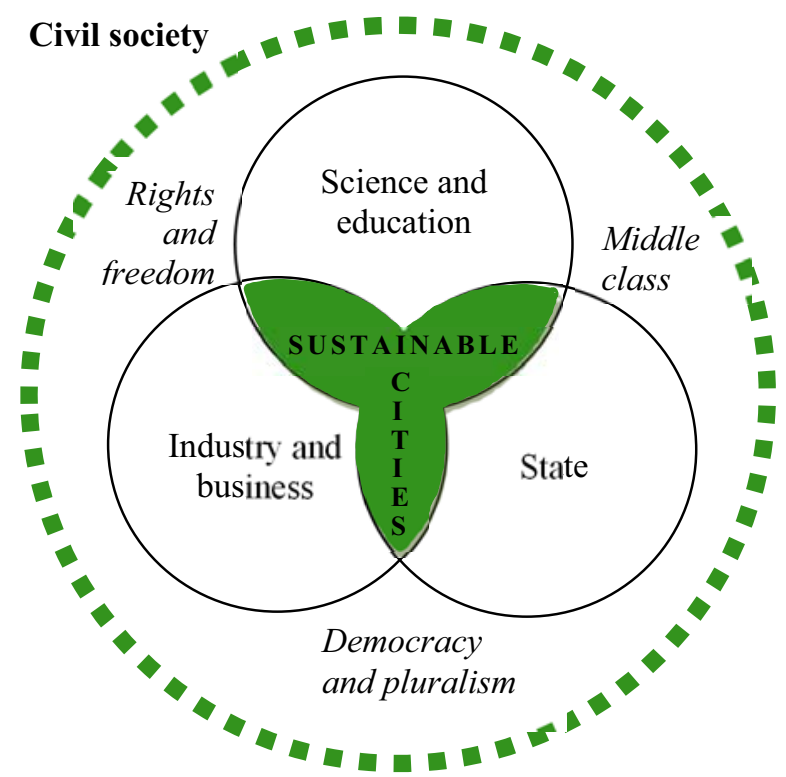

Fig. 5. Quadruple Helix-modeling scheme for innovation activity (based on [15]).

The analysis results of the changeability of the structure of innovative projects directions within the participative budgeting of Kyiv (Table 2) allow to speak about the optimistic scenario of transition of the capital of Ukraine to real rates of achievement of Sustainable 
Development Goals by 2030 (by overcoming the coronavirus pandemic and its consequences in the short or medium term perspective 2021-2023) under the condition of accelerating the transformation of the project structure towards the balance of economic, social and environmental factors, and at the same time increase funding by rising the volume of responsible investment.

Table 2. Projects of the participatory budget of Kyiv, 2017-2019 (project cost in 2019: UAH 50,000 - 3 million) (according to [18]).

\begin{tabular}{|c|c|c|c|c|c|c|c|c|c|c|}
\hline $\begin{array}{l}\text { Categories } \\
\text { of projects }\end{array}$ & Period & $\begin{array}{r}\text { Numl } \\
\text { all, }\end{array}$ & of pr & $\begin{array}{l}\text { ojects: } \\
, \%\end{array}$ & & $\underset{\% p}{\text { Numb }}$ & $\begin{array}{l}r \text { of votes cast, } \\
\text { year, trend }\end{array}$ & & $\begin{array}{l}\text { of projects: } \\
\text { winning, \% }\end{array}$ & \\
\hline \multirow{4}{*}{ Education } & $2017^{*}$ & 76 & 18 & 23.7 & 28020 & 28,3 & \multirow{3}{*}{$\begin{array}{l}\% \uparrow \\
50 \dagger \\
25\end{array}$} & 54355309 & 15026066 & 10.7 \\
\hline & $2018^{* *}$ & 75 & 28 & 37.3 & 31739 & 45,2 & & 25838568 & 10377291 & 40.2 \\
\hline & $2018^{* * *}$ & 165 & 29 & 17.6 & 172732 & 49,8 & & 285349395 & 57909982 & 20.3 \\
\hline & 2019 & 295 & 135 & 45.8 & 192596 & 39,5 & $2018 \quad 2019^{\prime}$ & 219802938 & 58345294 & 26.6 \\
\hline \multirow{4}{*}{ Sports } & 2017 & 89 & 12 & 13.5 & 22260 & 22,5 & \multirow{4}{*}{$30 \AA$} & 58286296 & 10848183 & 18.6 \\
\hline & 2018 & 42 & 14 & 33.3 & 12704 & 18,1 & & 14789451 & 5162387 & 34.9 \\
\hline & 2018 & 116 & 17 & 14.7 & 79027 & 22,8 & & 198933838 & 31331915 & 15.8 \\
\hline & 2019 & 138 & 38 & 27.6 & 79239 & 16,3 & & 126088215 & 20356399 & 16.1 \\
\hline \multirow{4}{*}{$\begin{array}{l}\text { Culture, } \\
\text { tourism }\end{array}$} & 2017 & 65 & 3 & 4.6 & 9912 & 10,0 & \multirow{4}{*}{$10 \uparrow$} & 44221186 & 1918735 & 4.3 \\
\hline & 2018 & 21 & 5 & 23.8 & 4657 & 6,6 & & 7526261 & 1742731 & 23.2 \\
\hline & 2018 & 34 & 4 & 11.8 & 24325 & 7,0 & & 57255287 & 6925000 & 12.1 \\
\hline & 2019 & 78 & 15 & 19.2 & 37609 & 7,7 & & 66066332 & 14563595 & 22.0 \\
\hline \multirow{4}{*}{ Health } & 2017 & 38 & 5 & 13.2 & 14078 & 14,2 & \multirow{4}{*}{$\begin{array}{r}15 \uparrow \\
15 \uparrow\end{array}$} & 21855650 & 4166000 & 19.1 \\
\hline & 2018 & 6 & 2 & 33.3 & 2077 & 3,0 & & 1989936 & 800000 & 40.2 \\
\hline & 2018 & 28 & 3 & 10.7 & 23360 & 6,7 & & 47476184 & 5960893 & 12.6 \\
\hline & 2019 & 26 & 11 & 42.3 & 23388 & 4,8 & & 37274699 & 8039884 & 21.6 \\
\hline \multirow{4}{*}{$\begin{array}{l}\text { Social } \\
\text { protection }\end{array}$} & 2017 & 30 & 2 & 6.7 & 4476 & 4,5 & \multirow[t]{4}{*}{ 个 } & 19781017 & 1293100 & 6.5 \\
\hline & 2018 & 21 & 7 & 33.3 & 5601 & 8,0 & & 7320170 & 2750042 & 37.6 \\
\hline & 2018 & 22 & 1 & 4.6 & 4325 & 1,2 & & 35773962 & 1850000 & 5.2 \\
\hline & 2019 & 32 & 15 & 46.9 & 16578 & 3,4 & & 15263694 & 4191334 & 27.5 \\
\hline \multirow{4}{*}{$\begin{array}{l}\text { Infra- } \\
\text { structure }\end{array}$} & 2017 & 28 & 3 & 10.7 & 4843 & 4,9 & \multirow[t]{4}{*}{ 个 } & 18212164 & 2992549 & 16.4 \\
\hline & 2018 & 11 & 2 & 18.2 & 2593 & 3,7 & & \begin{tabular}{|l|}
2733409 \\
\end{tabular} & 799980 & 29.3 \\
\hline & 2018 & 12 & 0 & 0 & 2244 & 0,6 & & 20476000 & 0 & 0 \\
\hline & 2019 & 17 & 3 & 17.7 & 6942 & 1,4 & & 14717256 & 1042600 & 7.1 \\
\hline \multirow{4}{*}{ Security } & 2017 & 26 & 2 & 7.7 & 4103 & 4,1 & \multirow{4}{*}{5} & 16411352 & 1980719 & 12.1 \\
\hline & 2018 & 10 & 2 & 20.0 & 1175 & 1,7 & & 3642675 & 769895 & 21.1 \\
\hline & 2018 & 10 & 2 & 20.0 & 7320 & 2,1 & & 17709851 & 3780000 & 21.3 \\
\hline & 2019 & 16 & 4 & 25.0 & 3298 & 0,7 & & 13691455 & 1201973 & 8.8 \\
\hline \multirow{4}{*}{ IT } & 2017 & 19 & 0 & 0 & 1267 & 1,3 & \multirow{4}{*}{1} & 12263997 & 0 & 0 \\
\hline & 2018 & 7 & 2 & 28.6 & 2180 & 3,1 & & 2391115 & 785519 & 32.9 \\
\hline & 2018 & 15 & 1 & 6.7 & \begin{tabular}{|l|}
8577 \\
\end{tabular} & 2,5 & & 28383907 & 2000000 & 7.0 \\
\hline & 2019 & 17 & 1 & 5.9 & 3528 & 0,7 & & 21415954 & 741054 & 3.5 \\
\hline \multirow{3}{*}{ Others } & 2018 & 8 & 2 & 25.0 & 2572 & 3,7 & \multirow{3}{*}{$4 \uparrow$} & 2115105 & 503000 & 23.8 \\
\hline & 2018 & 10 & 0 & 0 & 2074 & 0,6 & & 16632020 & 0 & 0 \\
\hline & 2019 & 22 & 6 & 27.3 & 8081 & 1,7 & & 17586941 & 2251781 & 12.8 \\
\hline Energy & 2019 & 76 & 19 & 0.25 & 36505 & 7,5 & $\dot{\rightarrow} t$ & 48684801 & 7465896 & 15.3 \\
\hline Public space & 2019 & 55 & 18 & 32.7 & 34110 & 7,0 & $7 \uparrow$ & 49858463 & 11550493 & 23.2 \\
\hline \multirow{4}{*}{ Ecology } & 2017 & 40 & 7 & 17.5 & 10130 & 10,2 & 不 & 26317569 & 4218339 & 16.0 \\
\hline & 2018 & 17 & 1 & 5.9 & 3652 & 5,2 & $10^{\dagger}$ & 6182506 & 400000 & 6.5 \\
\hline & 2018 & 31 & 0 & 0 & 8768 & 2,5 & 2 & 56476009 & 0 & 0 \\
\hline & 2019 & 35 & 9 & 25.7 & 11848 & 2,4 & $\stackrel{t}{\geq}$ & 20965023 & 3302023 & 15.8 \\
\hline & 2018 & 13 & 2 & 10,9 & 1299 & 1,8 & $\uparrow$ & 4452347 & 799948 & 18.0 \\
\hline Civil society & 2018 & 30 & 1 & 3.3 & 14331 & 4,1 & $7 \dagger$ & 53802254 & 2000000 & 3.7 \\
\hline & 2019 & 330 & 44 & 13.3 & 33618 & 6,9 & $2 t$ & 83361237 & 7862000 & 9.4 \\
\hline & 2017 & 411 & 52 & 12.7 & 99089 & 100 & 个Mln $U A H^{* * * *}$ & 271704540 & 42443691 & 15.6 \\
\hline & 2018 & 231 & 67 & 29.0 & 70249 & 100 & $140^{\dagger}$ & 78981543 & 24890793 & 31.5 \\
\hline Iotal & 2018 & 473 & 58 & 12.3 & 347083 & 100 & 40 & 818268707 & 111757790 & 13.7 \\
\hline & 2019 & 1137 & 318 & 28.0 & 487340 & 100 & & 734777008 & 140914326 & 19.2 \\
\hline
\end{tabular}

*Cost of projects (UAH): 1 thous. $-1 \mathrm{mln},{ }^{* *} 1$ thous. -400 thous., ${ }^{* * *} 401$ thous. $-2 \mathrm{mln},{ }^{* * * *}$ Trend of total project cost 


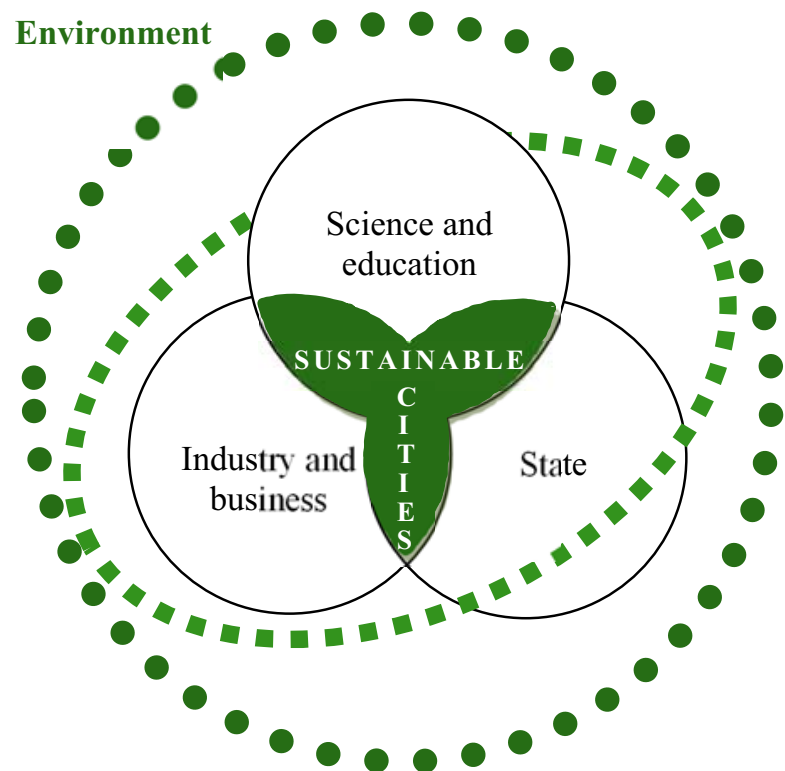

Fig. 6. Quintuple Helix-modeling scheme for innovation activity (based on [16]).

Based on these results and taking into account the experience of Germany [22; 23], as well as recommendations for ecologically oriented recreational development $[24 ; 25]$ and the introduction of international standards to strengthen the resistance to the coronavirus pandemic [26], an indicative structure as a benchmark for the sustainability of Kyiv city in the medium term is proposed in the paper (Fig. 7).

\section{Science + Education $\rightarrow \rightarrow \rightarrow$ Environment}

\section{0-2023}
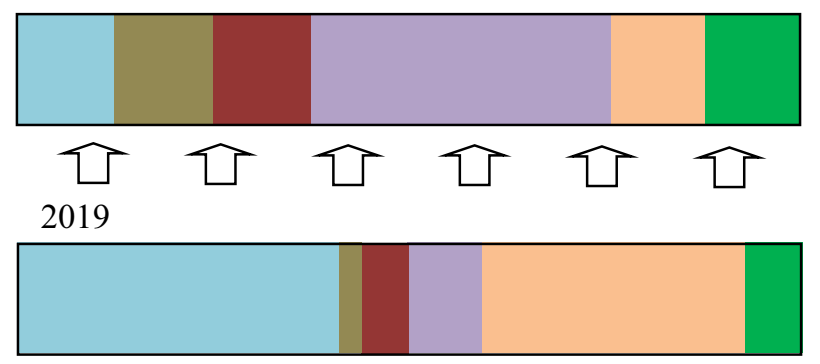

2018

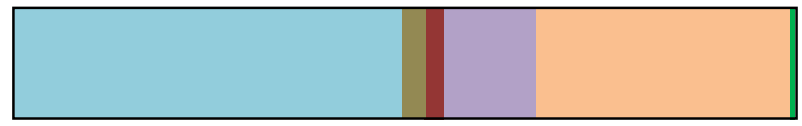

2017

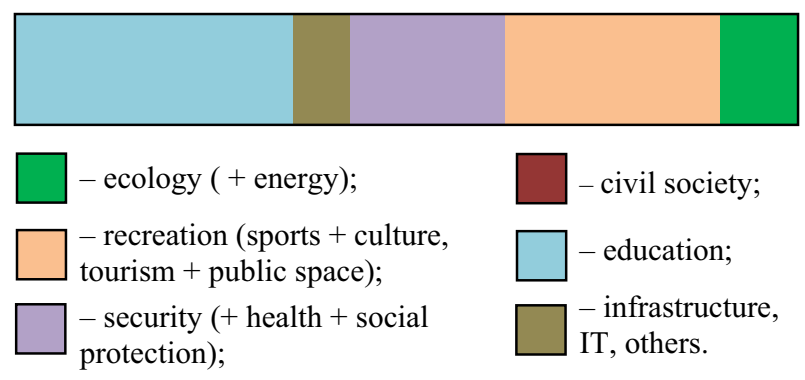

Fig. 7. Structure of project directions (according to the total cost of winning projects) within the participatory budget of Kyiv.
The main share (it is proposed to triple its weight in order to accelerate the response to the pandemic) in the structure belongs to security. Other shares have an approximately equal weight, which corresponds to the principle of balance: the weight of ecology, infrastructure and civil society increases, but the weight of recreation, and education decreases, which is possible in the conditions of distance learning.

\section{Discussion}

Trends and prospects for the development of educational sector and its support in the side of the state and international organizations, in particular in Germany, which has one of the most progressive and effective systems of education and science [27-33] within participatory budgeting requires a balanced approach to attracting investment. It is necessary to strengthen the role of public-private partnership, which will ensure the guarantee of completion the projects in full of planned costs, as well as control over the quality of their implementation, including in the period after the completion of projects. This provision is principal: the sustainability of cities and, in particular, of educational sector means ensuring the support of realization innovative, especially inclusive, projects over a long period of time, now, as a rule, till 2030. For countries with economies in transition responsible investment is extremely important, especially aimed at the development of inclusive education.

\section{Conclusion}

The study of the participatory budgeting contribution to the sustainability of the city, on the example of Kyiv in Ukraine, based on the methodological approach of innovative helix-modeling is conducted in the paper. The evolution of helix-models, ranging from the basic model (triple helix model) to the ecologically integrated model (quintuple helix model) demonstrates the importance of not just taking into account the additive principle, but the integration of five components (science and education, business, government, public, environment) in the plane of innovative projects implementation formed on the principles of sustainability and inclusiveness. The analysis of the participatory budgeting structure, aimed at increasing the sustainability of Kyiv city, confirms the positive dynamics relevant to the evolutionary approach of helix-modeling. Given the pandemic crisis, as well as the peculiarities of the Sustainable Development Goals implementation in Ukraine, a benchmark of this structure in the medium term 2021-2023 is proposed in a study, which is based on a balance of six components: ecology, recreation, security, civil society, infrastructure projects and education. Taking into account the specifics of the current situation, security has the largest share, the share of education and recreation should decrease, but the share of the environment, including the recreational environment increases due to the expansion of "green" public space. An increment of the share of civil society to accelerate the development of democracy in the country is also important. 
Prospects for further research are related to the analysis of the possibilities of applying the participatory budgeting mechanism within the European Green Deal, in particular such strategies as "A zero pollution ambition for a toxic free environment", "Accelerating the shift to sustainable and smart mobility", and "Supplying clean, affordable and secure energy" at the municipal level.

This research is part of the National Academy of Science of Ukraine's research projects: "Inclusion of the experience economy in the nature management" (No. 0119U000229), "Investment and innovation policy dominants of national economy's nature management» (No. 0120U100160).

\section{References}

1. K. Borghys, S. van der Graaf, N. Walravens, M. van Compernolle, Multi-Stakeholder innovation in smart city discourse: quadruple helix thinking in the age of "platforms". Frontiers in Sustainable Cities 2(5) (2020). doi:10.3389/frsc.2020.00005

2. N. Mueller, D. Rojas-Rueda, H. Khreis, et al., Changing the urban design of cities for health: the superblock model. Environmental International 134, 105132 (2020). doi:10.1016/j.envint.2019.105132

3. E. P. Trindade, M.P.F. Hinnig, E.M. da Costa, et al., Sustainable development of smart cities: a systematic review of the literature. Journal of Open Innovation 3, 11 (2017). doi:10.1186/s40852-017-0063-2

4. O. V. Prokopenko, V. M. Kysly, H. M. Shevchenko, Peculiarities of the natural resources economic estimation under the transformational conditions. Economic Annals-XXI 7-8(1), 40-43 (2014), http://soskin.info/en/ea/2014/7-8/contents_10.html. Accessed 30 Dec 2020

5. European Commission website, A European Green Deal. https://ec.europa.eu/info/strategy/priorities2019-2024/european-green-deal_en

(2020). Accessed 30 Dec 2020

6. Sustainable Development Goals Ukraine (Voluntary National Review, 2020), https://sustainabledevelopment.un.org/content/docu ments/26295VNR_2020_Ukraine_Report.pdf. Accessed 30 Dec 2020

7. M. Petrushenko, H. Shevchenko, B. Burkynskyi, N. Khumarova, A game-theoretical model for investment in inclusive recreation and wellness in Ukraine: the regional context. Investment Management and Financial Innovations 16(4), 382394 (2019). doi:10.21511/imfi.16(4).2019.32

8. H. M. Shevchenko, Regulatory policy and optimization of investment resource allocation in model of functioning recreation industry. Baltic Journal of Economic Science 3(1), 109-115 (2017). doi:10.30525/2256-0742/2017-3-1-109-115

9. Y. Sintomer, C. Herzberg, A. Röcke, G. Allegretti, Transnational models of citizen participation: the case of participatory budgeting. Journal of Public Deliberation 8(2) (2012). doi:10.16997/jdd.141
10. C. Herzberg, 10 Jahre Bürgerhaushalte in Deutschland: eine Bilanz. JB StadtRegion 1, 105117. https://www.budrichjournals.de/index.php/stadtregion/article/view/4700 (2010). Accessed 02 Mar 2021

11. S. H. Schneider, Bürgerhaushalte in Deutschland. Individuelle und kontextuelle Einflussfaktoren der Beteiligung (Springer VS, Wiesbaden, 2018)

12. M. Gibbons, H. Nowotny, S. Schwartzman, P. Scott, M. A. Trow, The new production of knowledge (SAGE Publications, Thousand Oaks, 1994)

13. H. Etzkowitz, L. Leydesdorff, The triple helix university-industry-government relations: a laboratory for knowledge based economic development. EASST Review 14, 14-19 (1995)

14. E. G. Carayannis, D. F. J. Campbell, in Knowledge creation, diffusion, and use in innovation networks and knowledge clusters: a comparative systems approach across the United States, Europe, and Asia (Praeger Publishers, 2006), pp. 1-25

15. E. G. Carayannis, D. F. J. Campbell, "Mode 3" and "quadruple helix": toward a 21 st century fractal innovation ecosystem. International Journal of Technology Management 46(3/4), 201-234 (2009). doi:10.1504/IJTM.2009.023374

16. E. G. Carayannis, T. D. Barth, D. F. Campbell, The quintuple helix innovation model: global warming as a challenge and driver for innovation. Journal of innovation and entrepreneurship 1(2) (2012). doi:10.1186/2192-5372-1-2

17. E. G. Carayannis, D. F. J. Campbell, in Encyclopedia of creativity, invention, innovation and entrepreneurship, ed. by E. G. Carayannis, I. N. Dubina, et al. (2013), pp. 1293-1300. doi:10.1007/978-1-4614-3858-8_310

18. Public budget. Kyiv, https://gb.kyivcity.gov.ua/. Accessed 30 Dec 2020

19. State Statistics Service of Ukraine. Income and living conditions (2020), http://www.ukrstat.gov.ua/. Accessed 30 Dec 2020

20. A. Baturin, M. Bondar, G. Kovalchuk, et al., Rating of the ecological security of regions. Where is the cleanest air in Ukraine? (Focus, 31 Jan 2020), https://focus.ua/ukraine. Accessed 30 Dec 2020

21. J. N. Kimatu, Evolution of strategic interactions from the triple to quad helix innovation models for sustainable development in the era of globalization. Journal of Innovation and Entrepreneurship 5(16) (2016). doi:10.1186/s13731-016-0044-x

22. S. H. Schneider, S. Busse, Participatory budgeting in Germany - a review of empirical findings. International Journal of Public Administration 42(3), 259-273 doi:10.1080/01900692.2018.1426601

(2019).

23. A. Röcke, in Framing citizen participation (Palgrave Macmillan, London, 2014). doi:10.1057/9781137326669_9 
24. H. M. Shevchenko, V. M. Pakhomov, M. M. Petrushenko, Economic and legal issues of rural and recreational land use in Ukraine. Economic AnnalsXXI 1-2(156), 54-58 (2016). doi:10.21003/ea.V1560012

25. H. Shevchenko, M. Petrushenko, B. Burkynskyi, N. Khumarova, Y. Opanasiuk, Management of wellness and recreation in urban agglomerations. Problems and Perspectives in Management 18(1), 231-241 (2020). doi:10.21511/ppm.18(1).2020.20

26. ISO. COVID-19 response: freely available ISO standard (Apr 2020), https://www.iso.org/covid19. Accessed 30 Dec 2020

27. B. Weber, Economic education in Germany. Journal of Social Science Education 1 (2002). doi:10.4119/UNIBI/jsse-v1-i2-458

28. K. Hüfner, Governance and funding of higher education in Germany. Higher Education in Europe 28(2), 145-163, (2003). doi:10.1080/03797720304104

29. R. D. Anderson, Germany and the humboldtian model (Oxford Scholarship Online, 2004). doi:10.1093/acprof:oso/9780198206606.003.0004

30. D. Dohmen, in National systems of innovation in comparison, ed. by U. Schmoch, C. Rammer, H. Legler (Dordrecht, Springer, 2006). doi:10.1007/14020-4949-1_14

31. OECD. Education policy outlook Germany (2014), http://www.oecd.org/education/highlightsgermany.h tm. Accessed 30 Dec 2020

32. Federal Ministry of Education and Research. The budget of the Federal Ministry of Education and Research, https://www.bmbf.de/en/education-andresearch-priority-areas-of-federal-governmentpolicy-1410.html. Accessed 30 Dec 2020

33. Ü. Burhan, K. Duruhan, Scrutinizing german education system in terms of its effect on social and cultural structure, employment and economy. OPUS 22(15), 801-822 (2020). doi:10.26466/opus.596969 